\title{
A Pragma-Dialectical Approach to Argumentative Discourse
}

\author{
Touria Drid \\ Kasdi Merbah University, Algeria
}

\section{Introduction}

The examination of argumentative discourse is the exploration of a very knotty type of communication. Dating back to Greek times, the study of argumentation has been approached from divergent angles over centuries. Colliding outlooks that stem from the ancient disciplines of logic, rhetoric and dialectic have been held, but theoretical affinities and mutual influences between the various perspectives in the field have also been detected. The modern theory of argumentation has undergone marked developments in a variety of directions, which have turned it into one of the most heterogeneous scholarly fields. Pragma-dialectics is an approach to argumentation initiated by Frans van Eemeren and Rob Grootendorst in the 1970s at the Speech Communication Department of the University of Amsterdam. It has gained ground among the most recent and popular multidisciplinary approaches to argumentative discourse. The model is distinguished by a set of theoretical assumptions regarding the nature of argument which are translated into procedural tools to analyse this kind of discourse. It has been applied to the examination of a variety of spoken and written argumentative genres, yielding practical outcomes.

\section{General Orientation of Pragma-dialectics}

In the literature, an important distinction in approaching argumentative discourse is drawn between the descriptive movement and the normative (or critical) one. The paragma-dialectical theory pursues a binary perspective which unites normativity and description as regards its object of study. Descriptivists advocate an empirical examination of the real use of language. Van Eemeren et al. (1993) elucidate that it is the practice of linguists to favour empirical investigation of discourse as a sample of actual verbal communicative experience. It is optimal for them to be impartial towards the data under examination, and this is considered a basic 
building block of linguistic science. They also clarify that humanistic research, such as in modern logic and rhetoric, is normative, for it takes an evaluative attitude as regards argumentative practice. It tries to evaluate the way people argue. Formal logicians, for example, opt for an idealised investigation, namely, assessing argumentative language by reference to some pre-established norms of reasonableness. This perspective is not so much concerned with how people actually $d o$ argue as much as with how they should argue. The research programme which underlies the pragma-dialectical approach brings together the methodological poles of linguists and logicians by reconciling their empirical and regimental tendencies without undermining the essence of each, as van Eemeren, et al. (1993) put it, "We believe this integration can occur without reducing normative principles for reasonable discussion to anthropologically relative characterisations, and likewise without prefiguring the categories and principles of descriptive inquiry in a way that makes them immune to empirical disconfirmation" (pp. 1-2). Van Eemeren et al. (1996) argue that the two perspectives are apparently separate, but combining them constitutes an interesting outlook on which they establish their own theory of pragma-dialectics.

Like any approach to an already established area of investigation with a respectable history, pragma-dialectics handles argumentative discourse in interdisciplinary terms, aiming at its improvement. On the one hand, pragma-dialectics gives argumentation a pragmatic account by considering it from a speech act perspective. It is built partly on the Speech Act Theory. On the other hand, the procedural dialectical conceptualisation of argument, as opposed to the logical or rhetorical ones (Wenzel, 1992), gives the approach its normative orientation. This integration of insights gives the theory its actual shape and locates it in area that can safely be dubbed normative pragmatics. Pragma-dialecticians hold that unilateral approaches do not do justice to argumentative discourse. That is, adopting either a "descriptive" orientation or a "normative" one seems to be a partial treatment of the subject. Thus, they call for a comprehensive research programme which fuses these apparently irreconcilable outlooks in one model. Normative pragmatics has been expounded on at length in the basic literature on the subject (van Eemeren, 1992; van Eemeren et al., 1993; van Eemeren et al., 1996; van Eemeren \& Grootendorst, 1992; van Eemeren \& Grootendorst, 2004).

\section{Meta-Theoretical Principles of Pragma-Dialectics}

The initiators of pragma-dialectics construe it as the outcome of a whole research programme, which concretizes their general normative-descriptive orientation and 
which consists of a number of interrelated components. Van Eemeren (1992), and van Eemeren and Grootendorst (2004) distinguish five "estates" in the study of argumentation. They argue that a research programme that would account satisfactorily for argumentation with regard to its nature is the one that endeavours to unite methodically various realms considering them as interdependent parts. The five realms are (1) the philosophical estate, (2) the theoretical estate, (3) the analytical (or reconstruction) estate, (4) the empirical estate and (5) the practical estate. Also, they formulate four starting points for their approach to realize the objectives of the general programme. The four meta-theoretical principles, as developed by van Eemeren and Grootendorst (1984), aim at handling argumentation more adequately. This embraces the externalisation, functionalisation, socialisation and dialectification of the object of study.

The principle of externalisation, as explained in van Eemerenet al. (1996), states that argumentation is not an internal frame of mind or a psychological tendency, nor is it an abstracted personal chain of reasoning that starts from a set of premises leading logically to a conclusion. Pragma-dialecticians hold that the study of argumentation does not involve speculation on interior predispositions, even if they do contain potential mismatched views. It is rather concerned with what is said actually by a speaker in terms of implicit or explicit speech acts. The verbally expressed disparity of views, the commitments undertaken when performing argumentative speech acts in a given context and the resulting consequences form a focal object of study. It is stressed that a speaker is only held responsible for an argumentative position when the latter is publicly projected in discourse. Externalisation then shifts the investigation of argumentation from the philosophical sphere to a more objective sphere. By adopting this principle, pragma-dialectics satisfies the linguistic descriptive requirement as regards its object of study since it deals with the observable, actual utterances rather than mere speculations, intentions or other non-empirical constructs. This allows the analyst to make use of experimental tools when dealing with argumentation, hence positioning pragma-dialectics itself within the highly non-speculative approaches.

The principle of functionalisation states that argumentation should not be thought of as an isolated product, but rather as an ongoing verbal process closely bound to its context (van Eemeren \& Grootendorst, 1984). The utterances that compose argumentative discourse are regarded as purposive bits of language whose performance relates to precise conditions and whose ultimate function is the resolution of disagreement:

Our view departs from a strictly structural view of argument by emphasizing the function of argument in managing the resolution 
of disagreements. An emphasis on the functions of argumentation and on the interactional processes within which it occurs, allows us to describe and to evaluate argumentation according to its purposes. (Van Eemeren et al., 1993, p. 13)

Functionalisation is thus to stress the purpose for which argumentative utterances are performed in the process of communication by treating them as speech acts which are performed in the context of a resolving a difference of opinion.

The principle of socialisation accentuates the interactional dialogic nature of argumentation. Starting from the perspective that argumentation aims at convincing another party of the acceptability of a standpoint, the monologic treatment of the subject of study seems to be defective. Socialisation is fulfilled if the utterances produced by speakers are handled as segments of a dialogue between two or more parties, who presupposedly hold opposing roles: that of a protagonist and that of a real or anticipated antagonist. The two parties attempt jointly to resolve a divergence of viewpoints. Van Eemeren, Grootendorst, Snoeck Henkemans, et al. (1993), in this connection, state:

[Argumentation] is part of a procedure whereby two or more individuals who have a difference of opinion try to arrive at agreement ... It reflects the collaboration in which the protagonist in the fundamentally dialogical interaction responds to the _real or projected_questions, doubts, objections and counterclaims of the antagonist. (p.277)

By locating the verbal productions of the participants in such an interactional context, it would be possible to specify the real meanings of their speech acts on the basis of their roles in the interaction. On account of this, it seems more adequate in pragma-dialectics to study argumentation as an outcome of a surrounding social context.

The principle of dialectification assesses argumentative language in terms of some pre-established norms of a critical discussion whose aim is to resolve a disparity of opinion. These rules form a procedure that determines which speech acts play a productive role for the resolution to be achieved. Therefore, the discussion taking place is designated as a "regimented" discussion (van Eemeren \& Grootendorst, 2004). This gives pragma-dialectics its normative orientation and represents the theoretical foundation on which the ideal model of a critical discussion, as elaborated by the theorists of this approach, is built. It is against this model that actual argumentative practice is evaluated. It is important to note, as van Eemeren and Grootendorst (1992) argue, that a critical discussion can be explicit or implicit. 
When it is implicit, the speaker or writer envisages the way a standpoint might be received by a doubtful listener or reader and hence projects arguments to remove such anticipated doubts.

Taken together, the four principles of externalisation, functionalisation, socialisation and dialectification constitute a sound basis in the light of which the following cardinal definition of argumentation in the pragma-dialectical approach is suggested:

Argumentation is a speech act consisting of a constellation of statements designed to justify or refute an expressed opinion and calculated in a regimented discussion to convince a rational judge of a particular standpoint of the acceptability or unacceptability of that expressed opinion. (Van Eemeren \& Grootendorst, 1984, p. 18)

This definition summarises the four pillars of the pragma-dialectical conceptualisation of argumentation. First, it regards it as a speech act, in line with the functionalisation and externalisation principles. Also, it displays its dialogic nature, in line with the socialisation principle by recognising that there is a second party to whom argumentation is addressed. What is more, it conceives of argument as part of a regimented discussion, thus conforming to the dialectification principle. All in all, the four meta-theoretical principles are outlined to fix the central methodological pathways which the whole approach follows.

\section{Applying Speech Act Theory to Argumentation}

The pragmatic aspect of pragma-dialectics unfolds in its treatment of argumentation within the framework of the speech act theory, as laid down by Austin (1962) and developed later by Searle (1969, 1975a and 1975b) but with some adaptation. This is attained through considering the argumentative moves of argumentation as speech acts. It is therefore necessary to give paramount importance to the performance of these moves, the effects this performance has on the listener and the conditions under which it takes place. Van Eemeren and Grootendorst (1984) give a thorough discussion of how speech act theory is applied to the analysis of argumentative discourse. The whole paradigm is embedded within a postulated framework called the "ideal model of a critical discussion". 


\subsection{The Conceptualisation of Argumentation in Pragma-dialectics}

Pragma-dialecticians endeavour to offer a clear-cut definition to the argumentation seen as a speech act. In line with Austin's and Searle's outlooks, argumentation is regarded as an illocutionary act connected to the perlocutionary act of convincing, but because of some observed problems in the earlier speech act models, notably their restrictedness only to sentences with explicit illocutionary force and the oneto-one relationship between isolated sentences and illocutions, the notion compound illocution, or illocutionary act complex has been introduced:

We believe that argumentation can be treated as an illocutionary act complex. This act complex is composed of elementary illocutions which belong to the category of assertives and which at sentence level maintain a one-to-one ratio with (grammatical) sentences. The total constellation of the elementary illocutions constitutes the illocutionary act complex of argumentation, which at a higher textual level maintains, as a single whole, a one-to-one ratio with a (grammatical) sentence sequence. (Van Eemeren \& Grootendorst, 1992, p.34)

In this perspective, argumentation is construed as an illocutionary act related to a whole piece of discourse rather than a single sentence. The component parts belong to the category Searle (1975a) calls assertives. Taken together, however, they jointly have the communicative function of arguing and may lead to the interactional consequence of convincing. Van Eemeren and Grootendorst (1992) enumerate other differences between the speech act of argumentation and "elementary" speech acts, such as asserting, requesting, promising . . on the one hand, and other complex speech acts, such as amplifying, elucidating and explaining on the other.

A further borrowing from the speech act theory appears in specifying the felicity conditions under which the performance of the speech act complex of argumentation is believed to be successful, as shown in Table 1. Pragmadialecticians take as a starting point the fact that a speaker $\mathrm{S}$ has addressed to a listener L numerous statements which belong to the category of the assertives and which collectively form a constellation of statements $\left(S_{1}, S_{2}, \ldots S_{n}\right)$ that acts as proargumentation or contra-argumentation for an expressed opinion $\mathrm{O}$. 
Table 1

Felicity Conditions of the Speech Act Complex of Argumentation

\begin{tabular}{lll}
\hline Condition & Pro-argumentation & Contra-argumentation \\
\hline 1. The & The constellation of statements \\
Propositional & $S_{1}, S_{2}\left(\ldots S_{n}\right)$ consists of & $"$ \\
Content Condition & $\begin{array}{l}\text { assertives in which } \\
\text { propositions are expressed. }\end{array}$
\end{tabular}

2. The Essential Advancing the constellation of Condition

\section{Preparatory} Condition

\section{Sincerity}

Condition statements $S_{1}, S_{2}\left(\ldots S_{n}\right)$ counts as an attempt by $S$ to justify $\mathrm{O}$ to L's satisfaction, i.e. to convince $\mathrm{L}$ of the acceptability of $\mathrm{O}$.

1. $\mathrm{S}$ believes that $\mathrm{L}$ does not (in advance, completely, automatically) accept the expressed opinion $\mathrm{O}$.

2. $S$ believes $L$ will accept the propositions expressed in the statements $S_{1}, S_{2}\left(\ldots S_{n}\right)$

3. $\mathrm{S}$ believes that $\mathrm{L}$ will accept the constellation of statements $S_{1}, S_{2}\left(\ldots S_{n}\right)$ as a justification of $\mathrm{O}$.

1. $\mathrm{S}$ believes that $\mathrm{O}$ is acceptable.

2. $\mathrm{S}$ believes that the propositions expressed in the statements $S_{1}, S_{2}\left(\ldots S_{n}\right)$ are acceptable.

3. $\mathrm{S}$ believes that the constellation of statements $S_{1}$, $S_{2}\left(\ldots S_{n}\right)$ constitutes an acceptable justification of $\mathrm{O}$.
Advancing the constellation of statements $S_{1}, S_{2}\left(\ldots S_{n}\right)$ counts as an attempt by $S$ to refute $O$ to $L$ 's satisfaction, i.e. to convince $\mathrm{L}$ of the unacceptability of $\mathrm{O}$.

1. $\mathrm{S}$ believes that $\mathrm{L}$ (for the time being, in whole or in part, more or less) accepts the expressed opinion $\mathrm{O}$.

2. $S$ believes $L$ will accept the propositions expressed in the statements $S_{1}, S_{2}\left(\ldots S_{n}\right)$ 3. $S$ believes that $\mathrm{L}$ will accept the constellation of statements $S_{1}, S_{2}$ $\left(\ldots S_{n}\right)$ as a refutation of $\mathrm{O}$.

1. $\mathrm{S}$ believes that $\mathrm{O}$ is unacceptable.

2. $\mathrm{S}$ believes that the propositions expressed in the statements $S_{1}, S_{2}$ $\left(\ldots S_{n}\right)$ are acceptable.

3. $\mathrm{S}$ believes that the constellation of statements $S_{1}, S_{2}\left(\ldots S_{n}\right)$ constitutes an acceptable refutation of $\mathrm{O}$.

Note. $\mathrm{S}=$ speaker; $\mathrm{L}=$ hearer; $\mathrm{O}=$ opinion; $S_{n}=$ statement number $n$. Adapted from Speech Acts in Argumentative Discussions, by F. van Eemeren, 1992.

\subsection{The Model of a Critical Discussion}

Argumentative discourse in pragma-dialectics has a dialectical nature in relation to the dialectification principle. The participants are believed to be engaged in an 
argumentative discussion in which the first party (the protagonist) defends a standpoint and the second party (the antagonist) raises doubts against it. In the course of this discussion, the former attempts to convince the latter of the acceptability of their standpoints, while the latter keeps expressing their doubts or objections to these standpoints (van Eemeren, Grootendorst \& Snoeck Henkemans, 2002). An ideal model of a critical discussion is designed to provide a kind of regimentation to the practice of argumentation. The quality of argumentative exchanges is measured by reference to some standards of reasonableness extracted from this model. Basically, the ideal model of a critical discussion indicates the stages which interlocutors have to go through together with the relevant argumentative moves (in terms of speech acts) which they have to perform at each stage for the resolution of the dispute to be accomplished.

\subsubsection{Dialectical Stages}

Four dialectical stages can be distinguished in the process of resolving a difference of opinion, which the participants in an argumentative exchange of views have to pass through. These stages comply with the phases of a critical discussion. The first phase is the confrontation stage. At this level a disparity of opinion arises by advancing a standpoint and its being subjected to questioning or doubt. It is argued that this stage is a prerequisite for a critical discussion to take place (van Eemeren $\&$ Grootendorst, 2004). The second phase is the opening stage. It is at this juncture that interlocutors assume roles of a protagonist and antagonist, hence allowing a discussion to start, but without an ample common point of departure, a critical exchange of views would not be meaningful, as van Eemerenet al. (1996) put it:

It only makes sense to undertake an attempt to eliminate a difference of opinion by means of argumentation if such a starting point can be established. If there is no opening for exchanging views, then having a critical discussion is of no use. (p. 282)

The third stage is the argumentation stage. It is so called for it is the core of the critical discussion: discussants advance arguments for and against a standpoint in a critical manner for the purpose of resolving the difference of opinion. The way arguments hang together may take various forms. Van Eemeren and Grootendorst (2004) see that advancing and critically evaluating argumentation together form necessary and inseparable building blocks of this phase. The fourth stage, the concluding stage, is in essence the level at which the result of the discussion unfolds by resolving a difference of opinion in favour of one of the parties: either accepting the protagonist's standpoint and withdrawing the antagonist's doubts or retracting the standpoint itself, which signals its unacceptability. In van Eemeren's 
terms, concluding a discussion is determining "who won". At this point further differences of opinion might emerge and new discussions might start, with slight or radical modifications.

If one attempts to measure the degree to which the practice of argumentation conforms to the postulated stages of the ideal model, one would certainly observe the vast disparity between them. Van Eemeren (2015) in this respect, alleges"[the ideal model] does not provide a true-to-life description of argumentative reality ... argumentative discourse rarely, if ever, corresponds exactly to the ideal model" (p.491). The model is construed as having two crucial functions: a heuristic (or analytic) function and a critical function. The heuristic function is to guide the analyst in specifying and interpreting the aspects and elements needed for the evaluation of argumentation. The critical function is to establish standards according to which the speech acts constituting the exchange are judged as conforming to or deviating from a procedure that is resolution oriented (van Eemeren \& Grootendorst, 1992; van Eemeren \& Grootendorst, 2004; van Eemeren, Houtlosser \& Snoeck Henkemans, 2007).

\subsubsection{Speech Acts in a Critical Discussion}

Starting from Searle's (1975a) five-fold classification of speech acts into assertives, declaratives, commissives, expressives and directives, an attempt is made in pragma-dialectics to specify what speech acts do contribute to the resolution of a dispute in a critical discussion at the different stages. Generally, van Eemeren and Grootendorst (1984) see that the performance of speech acts by language users engaged in a discussion is confined just to assertives, commissives and directives, discarding declaratives and expressives in connection with what each language user should "do" at each stage and the contribution of his move to the resolution of the dispute. They also indicate that the only permissible operations in the discussion are those of negation and repetition.

\subsubsection{Rules of a Critical Discussion and Fallacies}

The ideal model of a critical discussion, as explained above, permits language users to undertake a critical discussion that is resolution oriented. Pragma-dialecticians add that along the different stages of the discussion, language users have to comply with a discussion procedure, the rules of which form a code of conduct. Any argumentative move that transgresses the code of conduct is regarded as a fallacy, using the traditional terminology. In what follows a brief account of the nature of the rules suggested and their related fallacies is presented. 
To start with, in Speech Acts in Argumentative Discussions (1984), van Eemeren and Grootendorst set a meticulous technical inventory of seventeen rules aimed at guiding rational discussants in their endeavour to resolve the dispute at issue. In this respect, they explain, "The rules we have formulated relate to the performance of speech acts in argumentative discussions and indicate the conditions that the usage of language users in a discussion has to meet in order to be able to contribute to the resolution of a dispute" (p. 175). It appears here that the gist of the code of conduct is the speech acts externalised by speakers and the directives governing their performance by interlocutors to settle a disagreement. The rules of discussion are meant to qualify language users to conduct themselves as rational discussants in addition to deterring anything that could hinder the resolution process. Elsewhere, the dialectical rules that represent a code of conduct are condensed in a simplified version to ten basic principles, or the "ten commandments" of a critical discussion (van Eemeren and Grootendorst, 1992; van Eemeren et al., 1996; van Eemeren, Grootendorst \& Snoeck Henkemans, 2002). They demonstrate how each one helps the interlocutors to arrive at fixing a dispute. The ten fundamental rules of the code of conduct are listed below:

RULE 1: (Freedom rule) Parties must not prevent each other from putting forward standpoints or casting doubt on standpoints.

RULE 2: (Burden-of-proof rule) A party who puts forward a standpoint is obliged to defend it if asked to do so.

RULE 3: (Standpoint rule) A party's attack on a standpoint must relate to the standpoint that has indeed been advanced by the other party.

RULE 4: (Relevance rule) A party may defend his or her standpoint only by advancing argumentation related to that standpoint.

RULE 5: (Unexpressed premise rule) A party may not falsely present something as a premise that has been left unexpressed by the other party or deny a premise that he or she has left implicit.

RULE 6: (Starting point rule) No party may falsely present a premise as an accepted starting point, or deny a premise representing an accepted starting point.

(Argument Scheme rule) A standpoint may not be regarded as

RULE 7: conclusively defended if the defence does not take place by means of an appropriate argument scheme that is correctly applied.

RULE 8: (Validity rule) The reasoning in the argumentation must be logically valid or must be capable of being made valid by making 
explicit one or more unexpressed premises.

RULE 9: (Closure rule) A failed defense of a standpoint must result in the protagonist retracting the standpoint, and a successful defense of a standpoint must result in the antagonist retracting his or her doubts.

RULE 10: (Usage rule) Parties must not use any formulations that are insufficiently clear or confusingly ambiguous, and they must interpret the formulations of the other party as carefully and accurately as possible.

Although the rules sketched out above are held to be conductive to fixing a dispute, pragma-dialecticians do assert that they are just necessary but by no means satisfactory in practice. Other factors are deemed to contribute to the resolution (van Eemeren \& Grootendorst, 2004).

Setting rules for argumentative discussions is the initial step to enter the area of fallacies in argumentation. By definition, a fallacy is a "deficient move" in argumentative discourse (van Eemeren, 2001a). In the pragma-dialectical framework, the deficiency of an argumentative move can only be determined if one refers to the code of conduct suggested in the theory, being the touchstone against which argumentative practice is evaluated. On this basis, a fallacy in this perspective is a violation by one of the parties engaged in a discussion, at any of the stages of the ideal model of a critical discussion, of some of the rules for the performance of speech acts that are conductive to the resolution. Van Eemeren (2001b) clarifies, "Only after it has become clear which specific criterion for satisfying a norm pertaining to a particular stage of the resolution process has not been met can it be determined which fallacy has been committed" (p.300). In brief, a fallacy can be said to be a speech act non-conforming to the rules of a critical discussion. Starting from the rules that constitute the code of conduct, pragmadialecticians classify the fallacies into ten basic categories, with subtypes, according to the rule being violated. In addition to that, they add a number of other fallacies that might intervene with the accomplishment of the resolution of the difference of opinion. Considering the rules that discussants have to adhere to and their related infringements, one could clearly perceive the normative orientation of the pragma-dialectical approach.

\section{Reconstructing Argumentative Discourse}

It has been shown that naturally occurring argumentative discourse, like many sorts of discourse, appears to pose difficulties of interpretation for analysts attempting to describe and assess its content. This is basically due to the fact that such content might not always be explicit or straightforward, or it might contain elements that 
cannot be said to belong to argumentation proper. On these grounds, the analyst has to reconstruct the discourse under examination in a form that highlights the essential components constituting the core of the description and evaluation in order to arrive at a correct interpretation. Of course, as Van Rees (2001) observes, the process of reconstruction cannot be undertaken in a theoretical vacuum, but rather it should be sited in a given theoretical conception of argumentation and a set of related standards for its evaluation. In her words, "Argument reconstruction... involves identifying and isolating all those and only those elements that are relevant to the theoretical perspective and for the theoretical purpose of the analyst" (p.166).

By defining argumentation as an attempt to resolve a difference of opinions through a regulated exchange of views within a model of a critical discussion, pragma-dialecticians attempt to provide a reconstruction of argumentative discourse with the objective of finding out the extent to which its pragmatic and dialectical layout leads to the resolution of the differences of opinion by focussing just on the aspects that are important for this resolution. Reconstruction, in this perspective, entails the production of an analytic overview, which unambiguously and comprehensively depicts the relevant parts of argumentation. When formulating an overview, the analyst makes use of specific operations and relies on precise linguistic and extra-linguistic contextual clues for an objective empirical justification of the reconstruction process.

\subsection{The Components of the Analytic Overview}

As regards the aspects of argumentative discourse which are crucial for the resolution of disputes, van Eemerenet al. (1996) point out that an adequate evaluation of argumentative discourse can only be reached if the analytic overview tackles a number of basic elements. These are (1) the standpoints existing in the discussion, (2) the positions assumed by the discussants together with their starting and concluding points, (3) the array of arguments advanced by the participants, (4) the structure of argumentation and (5) the argumentation schemes. To elucidate the outcomes of considering these aspects and their significance for the evaluation, a number of analytic questions can be formulated, as outlined in Table 2 . 
Table 2

Components of an Analytic Overview and their Significance for Evaluation

\begin{tabular}{|c|c|c|c|}
\hline $\begin{array}{l}\text { Aspect of } \\
\text { discourse }\end{array}$ & $\begin{array}{l}\text { Analytic } \\
\text { Question(s) }\end{array}$ & $\begin{array}{l}\text { Outcomes of } \\
\text { Analysis }\end{array}$ & $\begin{array}{l}\text { Significance for } \\
\text { evaluation }\end{array}$ \\
\hline $\begin{array}{l}\text { 1. Difference of } \\
\text { opinion }\end{array}$ & $\begin{array}{l}\text { - What kind is } \\
\text { the difference of } \\
\text { opinion? }\end{array}$ & $\begin{array}{l}\text { Single non-mixed/ } \\
\text { multiple non-mixed/ } \\
\text { single mixed/ } \\
\text { multiple mixed/ }\end{array}$ & $\begin{array}{l}\text { Determining whether } \\
\text { the existing } \\
\text { difference has been } \\
\text { resolved. }\end{array}$ \\
\hline $\begin{array}{l}\text { 2. Distribution of } \\
\text { roles }\end{array}$ & $\begin{array}{l}\text { - Which roles } \\
\text { are assumed by } \\
\text { the participants? }\end{array}$ & $\begin{array}{l}\text { Protagonist/ } \\
\text { antagonist }\end{array}$ & $\begin{array}{l}\text { Determining the party } \\
\text { in whose favour the } \\
\text { discussion has } \\
\text { terminated. }\end{array}$ \\
\hline 3. Arguments & $\begin{array}{l}\text { - What } \\
\text { arguments are } \\
\text { advanced in the } \\
\text { discussion? } \\
\text { - What premises } \\
\text { are expressed/ } \\
\text { unexpressed }\end{array}$ & $\begin{array}{l}\text { - An array of } \\
\text { arguments } \\
\text { - An array of } \\
\text { premises (expressed/ } \\
\text { unexpressed) }\end{array}$ & $\begin{array}{l}\text { Accounting } \\
\text { thoroughly for the } \\
\text { argumentation } \\
\text { advanced in the } \\
\text { discussion }\end{array}$ \\
\hline $\begin{array}{l}\text { 4. Argumentation } \\
\text { structure }\end{array}$ & $\begin{array}{l}\text { - How are the } \\
\text { arguments } \\
\text { related to each } \\
\text { other? }\end{array}$ & $\begin{array}{l}\text { Single/ multiple/ } \\
\text { compound structure }\end{array}$ & $\begin{array}{l}\text { Assessing the } \\
\text { adequacy and } \\
\text { coherence of } \\
\text { arguments }\end{array}$ \\
\hline $\begin{array}{l}\text { 5. Argumentation } \\
\text { schemes }\end{array}$ & $\begin{array}{l}\text { - How are the } \\
\text { premises related } \\
\text { to the } \\
\text { standpoints? }\end{array}$ & $\begin{array}{l}\text { Token/similarity/ } \\
\text { consequence }\end{array}$ & $\begin{array}{l}\text { Assessing the } \\
\text { relationship between } \\
\text { premises and } \\
\text { standpoints. }\end{array}$ \\
\hline
\end{tabular}

Constructed in such a way, an analytic overview, as van Eemeren, Grootendorst, Jackson, et al. (1993) observe, offers a proper understanding of argumentative discourse, a possibility of explaining its coherence and a reliable foundation for its assessment.

\subsection{Analytic Operations}

Four analytic operations, or transformations, are made use of to cast discourse into a dialectical form: deletion, addition, substitution and permutation. Thus the discourse resulting from the reconstruction process may differ from the actual discourse in a number of ways. Van Eemeren (2006) considers these transformations as tools employed to externalize the commitments of participants, which form the ground for an adequate evaluation of argumentative discourse. According to Van Eemeren and Grootendorst (1989), deletion consists in selecting 
only those elements that are of direct relevance to the resolution process and eliminating every other element which seems superfluous, repetitive or digressive. Addition consists in appending the missing parts of discourse which are contributory to resolving the dispute but are left implicit or unexpressed. One can postulate the schema that represents the addition transformation as follows:

Original formulation

(incomplete)

$\mathrm{X}$

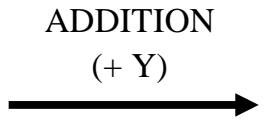

Reconstruction

$$
\mathrm{X}+\mathrm{Y}
$$

It is shown that one of the most frequent uses of this transformation is to render the communicative force of standpoints and arguments unequivocal where this is left hidden (van Eemeren \& Grootendorst, 2004). Substitution involves rephrasing the elements of discourse with regard to their function and disambiguating obscure expressions by using standard phrases instead. In the same way, the substitution transformation can be reduced to the schema below:

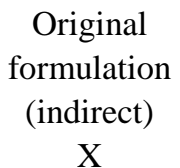

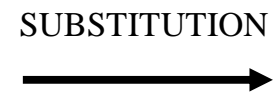

\section{Reconstruction (direct)}

$\mathrm{Z}$

Substitution is essentially made use of in cases of indirectness. An indirect standpoint or argumentation, which are usually confusing, are replaced by a direct standard formulation for them, allowing a single reading. For example, the directive, "Definitely ask her [Miriam]. By all means!" is substituted by the formulation: "My standpoint is that Miriam should be invited to John's party" (van Eemeren \& Grootendorst, 2004). Permutation involves the rearrangement of the constituents of discourse following the stages of the ideal model of a critical discussion. By applying this transformation, the elements of discourse may maintain their original positions, or they may be shifted to comply with the ideal model structure. The four analytical transformations have the merit of interpreting the verbal moves comprising argumentative discourse in pragma-dialectical terms (van Eemeren et al., 1993).

\section{Conclusion}

The pragma-dialectical approach has brought the study of argumentation signbificant outcomes. Most importantly, the introduction of the pragmatic component made it possible to see argumentation from a functional angle. Further, the extension of the analysis over the sentential boundaries has broadened the scope of the Speech Act Theory itself, permitting the analyst to consider the way a 
constellation of elementary speech acts acting together leads to the fulfillment of the higher order communicative goal of convincing. The normative layer of the approach appears in regarding argumentative discourse as a regulated, rulegoverned critical discussion. In recent years, pragma-dialecticians have recognized the need to bring argumentation to the contextual requirements together with reasonableness requirements for more effectiveness. This shift towards rhetorical concerns has led to a significant advancement in the pragma-dialectical approach by introducing the concept of strategic maneuvering. Van Eemeren (2010) argues that widening the pragma-dialectical approach to argumentation in strategic maneuvering terms has the outcome of yielding more affluent and more accurate tools to explore and assess argumentative discourse. On the whole, the pragmadialectical approach has now become a major school of thought through the more specialized analyses which are undertaken by its initiators and followers in more specific domains of argumentative discourse.

\section{References and notes:}

1. Austin, J. L. (1962). How to do things with words. Oxford: Oxford University Press.

2. Searle, J. (1969). Speech acts. Cambridge: Cambridge University Press.

3. Searle, J. (1975a). A classification of illocutionary acts. Language in Society, 5(1), $1-23$.

4. Searle, J. (1975b). Indirect speech acts. In P. Cole and J. L. Morgan (Eds.), Syntax and semantics 3: Speech acts (pp. 59-82). New York: Academic Press.

5. Van Eemeren, F. H. (1992). Argumentation studies: Five estates. In W.L. Benoit, D. Hample, and P.J. Benoit. (Eds.), Readings in argumentation (pp. 615-654). Berlin. New York: Foris Publications.

6. Van Eemeren, F. H. (2001a). Fallacies. In F. H. Van Eemeren (Ed.), Crucial concepts in argumentation theory (pp. 135-164). Amsterdam: Amsterdam University Press.

7. Van Eemeren, F. H (2001 b). Fallacies. In Encyclopedia of rhetoric (pp. 295-301). New York: Oxford University Press.

8. Van Eemeren, F. H. (2006). Pragma-dialectical theory of argumentation. In B. Whaley \& W. Samter (Eds.), Explaining communication: Contemporary theories and exemplars (pp. 351-382). Mahwah, NJ: Lawrence Erlbaum.

9. Van Eemeren, F. H. (2010). Strategic maneuvering in argumentative discourse. Amsterdam/Philadelphia: John Benjamins Publishing Company.

10. Van Eemeren, F. H. (2015). Reasonableness and Effectiveness in Argumentative Discourse: Contributions to the Development of Pragma-Dialectics. Cham, Switzerland : Springer International Publishing AG.

11. Van Eemeren, F. H. \& Grootendorst, R. (1984). Speech acts in argumentative discussions. Dordrecht, the Netherlands: Foris Publications. 
12. Van Eemeren, F. H. \& Grootendorst, R. (1992). Argumentation, communication and fallacies: A pragma-dialectical perspective. Hillsdale, New Jersey: Lawrence Erlbaum Associates.

13. Van Eemeren, F. H. \& Grootendorst, R. (2004). A Systematic theory of argumentation: The pragma-dialectial approach. Cambridge: Cambridge University Press.

14. Van Eemeren, F. H., Grootendorst, R., Jackson, S. \& Jacobs, S. (1993). Reconstructing argumentative discourse. Tuscaloosa, Alabama: University of Alabama Press.

15. Van Eemeren, F. H., Grootendorst, R. \& Snoeck Henkemans, A. F. (2002). Argumentation: Analysis, evaluation, presentation. Mahwah, New Jersey: Lawrence Erlbaum Associates

16. Van Eemeren, F. H., Grootendorst, R., Snoeck Henkemans, A. F., Blair, J.A., Johnson, R. H., Krabbe, E. C.W. et al. (1996). Fundamentals of argumentation theory: A handbook of historical backgrounds and contemporary developments. Mahwah, New Jersey: Lawrence Erlbaum Associates.

17. Van Eemeren, F. H. Houtlosser, P. \& Snoeck Henkemans, A. F. (2007). Argumentative indicators in discourse: A pragma-dialectical study. Dordrecht, the Netherlands: Springer.

18. Van Rees, M. A. (2001). Argument interpretation and reconstruction. In F. H. Van Eemeren (Ed.), Crucial concepts in argumentation theory (pp.165-199). Amsterdam: Amsterdam University Press.

19. Wenzel, J. W. (1992). Perspectives on argument. In W.L. Benoit, D. Hample, and P. J. Benoit. (Eds.), Readings in argumentation (pp. 121-143). Berlin: Foris Publications.

\title{
Summary
}

\section{A Pragma-Dialectical Approach to Argumentative Discourse}

\author{
Touria Drid \\ Kasdi Merbah University, Algeria
}

Theoretical and procedural diverseness is a feature characterising the study of argumentation. The common core in all perspectives is to examine a type of discourse that attempts to convince another party of the acceptability of one's view(s) through a set of arguments, but what differs, to a larger or lesser extent, is the theoretical apparatus through which discourse is scrutinised. The present paper offers a general account of the pragma-dialectical approach to argumentation. Expatiating on the principal theoretical and methodological lines on which the theory proceeds, the paper aims at delineating the analytical tools provided in this paradigm to handle the intricacies of argumentative discourse.

Keywords: Argumentation, dialectic, logic, pragma-dialectics, speech act. 